\title{
Comparison of consumer preferences of dog food products between Thailand and Singapore using choice-based conjoint analysis
}

- Phaosathienpan Sarun ${ }^{\text {** }}$

- Leong Jasmine ${ }^{b}$

- Tengpongsathon Kallayanee ${ }^{a}$

aFood Science Division, Faculty of Agro- Industry, King Mongkut's Institute of Technology Ladkrabang, Bangkok, Thailand 10520.

bSchool of Chemical and Life Sciences, Singapore Polytechnic, 500, Dover Road Singapore 139651

*Corresponding Author: sphaosat@gmail.com, Tel: +6681 266 9080, +662 3298526 Fax: +662 3298527

(Manuscript Received on September 25 ${ }^{\text {th }}$, 2014; Manuscript Revised December $5^{\text {th }}$, 2014)

\begin{abstract}
This research investigated the difference in consumer perception of dog food products between Thais and Singaporeans using ChoiceBased Conjoint Analysis (CBC). The empirical analysis used consumer-level questionnaires to elicit the information ( $n=184$ for Thai consumers and $n=141$ for Singaporean consumers) with regards to four attributes (packaging format, price, brand quality and nutrition) with three predefined elements for Thai consumers (packaging format: canned, pouch, dry; price: 85 Baht, 135 Baht, 165 Baht per kg; brand quality: unbranded, commercial, premium; nutrition: fulfilled, silky fur and skin condition, dog's preference) and for Singaporean consumer (packaging format: canned, pouch, dry; price: < $S \$ 5, \quad S \$ 5-\$ 7,>S \$ 7$ per $\mathrm{kg}$; brand quality: supermarket, premium, holistic; nutrition:

The results of conditional logistic regression suggested that "premium", "dry", "silky fur and skin condition" were important elements for Thai consumers, while "dry", "holistic brand" and "specific nutrition" were important elements for Singaporean consumers. The "price" attribute did not contribute significantly to consumer preferences in both countries. In addition, CBC showed an overestimation in values of elements of dog food products. This may have resulted from respondents having focus on their preferred elements and ignored other elements. It was also found that the "dry" and "holistic" elements were the main dominating attributes for Singaporean and Thai consumers respectively. The comparison of the $C B C$ results between both countries has helped to identify the potential profile of dog food products.
\end{abstract} general, specific, dog's preference).

Keywords: Choice-Based Conjoint Analysis, Preference measurement, Dog food, Cross Cultural Study 


\section{INTRODUCTION}

The consumption of $\operatorname{dog}$ food in Thailand and Singapore has been continually growing recently. Nowadays dogs have become one important member of family and consumers believe that the food feeding their dogs should be as good as the food they consume themselves [1,2]. These trends led to the development of premium brands that contain added ingredients and formulations following the trends for human food [3]. Dog food products that contain functional ingredients become more prominent as their labels claimed that these products have better quality and are healthier for digestion, immune system and joint health. These ingredient patterns are also found in the human nutrition market [1]. In order to be successful products in market, the pet food companies need to focus on product innovation and product development oriented to consumer preferences. However, the evaluation of preferences of dog food product is still challenging since dogs lack the linguistic capabilities to express themselves and their owners have to determine dog food acceptability before serving it [3]. This phenomenon results in an increasing demand for faster and more efficient approaches in product development in pet food manufactures.

In recent years, many studies have used ChoiceBased Conjoint Analysis (CBC) to measure consumer preference toward food products [4,5]. $\mathrm{CBC}$ is a method used to determine how consumer value different product concepts in term of utility value. The utility value, obtained from weighting the importance of attributes and elements in product profiles, allows product developers to identify products with high potential. As cultural differences might occur it is interesting to study the influences of dog food characteristics toward the owner preference on consumers from different cultures.
Therefore, the objective of this research was to investigate the difference in consumer preference on dog pet food products between Thais and Singaporeans by using CBC method. Understanding the relevant attribute that drive consumers liking will help product developers to identify high potential concepts of dog food product that is most preferred in both countries.

\section{CHOICE-BASED CONJOINT ANALYSIS (CBC)}

Choice-Based Conjoint analysis, also called Choice Experiment (CE), is one of the most frequently used methods in the exploration of consumer preference by means of questionnaire. The $\mathrm{CBC}$ is based on the presentation of product concepts made of different attributes and elements to the respondent. The respondent is then asked to choose the most preferred product concept in each choice set. This method can be applied to evaluate consumers' preference of "complex goods" that comprise several attributes and elements. The CBC method was created for overcoming several critical assumptions inherent to the traditional Conjoint Analysis (CA) that could lead to incorrect predictions [4]. CBC has gain popularity because it is more realistic and easier for the respondents than CA. In CBC consumers have to choose the preferred product among alternatives which is similar to what consumers actually do at the market place. Finally, CBC estimates the preferences in term of utility values by using Conditional Logit (CL) model [4].

\subsection{The structure of choice set in CBC}

The CBC questionnaire includes several question sets or "choice set". Each choice set is formed by two or more product concepts or "alternative choice" that is constructed from product attributes and their levels or elements [6]. Practically, CBC offers a bundle of 
choice set which have two or more "alternative choices" to the respondents. Respondents are asked to choose only one alternative (the one they most prefer) in each choice set. An example of choice set is shown in Table 1.

In addition, a "no-choice" alternative is often added to each choice set to avoid to force the respondent to choose a product concept when there are not any preferred alternatives in the choice set [6]. However, it should be noted that respondents may choose "no-choice" because the element they expected is not included in the alternative in the choice set. Alternatively, respondents may choose the "no-choice" in order to avoid the difficult alternative choice [6].

Table 1. An example of a choice set in CBC

If you were in the market to buy dog food product, which one would you choose?

\begin{tabular}{llll}
\hline Attributes & Alternative "A" & Alternative "B" & Alternative "C" \\
\hline Packaging format & Canned & Pouch & \\
Price per Kg. & 135 baht & 85 baht & Neither alternative "A" \\
Brand Quality & Commercial Quality & Premium Quality & nor "B" I preferred \\
Nutrition & Fulfilled nutrition & Dog's preference & \\
\hline
\end{tabular}

\subsection{The methodology of CBC}

The CBC methodology is based on Lancaster's Theory of Value which stated that utilities for products or services can be decomposed into separable utilities for their attributes [4] and on the Random Utility Theory where the utility value is divided into two components: systematic and random [7]. The systematic component is the utility value that is measurable from the empirical study and the random component or "error term" is the utility value that is unobservable from the empirical study. These two components allow us to determine the utility value where respondent choose the alternative that has the higher level of utility in choice set [8]. From Lancaster's Theory of value, the utility function of individual $n$ for alternative $i$ is presented in Equation 1 below:

$$
\mathrm{U}_{\text {in }}=\mathrm{V}_{\text {in }}\left(\mathrm{Z}_{\mathrm{i}}\right)+\varepsilon_{\text {in }}
$$

where $U_{\text {in }}$ represents the utility value provided by alternative $i$ for individual $n, \mathrm{~V}_{\text {in }}$ is the systematic component or measurable component of utility, $\mathrm{Zi}$ is a vector of attributes of the alternative such as "format", "price", "quality-brand" and "nutrition". $\varepsilon_{\text {in }}$ is the random error term or unobservable factors
$[4,8]$. From the Random Utility Theory, the probability that individual $n$ choose the alternative $i$ denoted by $\operatorname{Pr}\left(\mathrm{i} \mid \mathrm{C}_{\mathrm{n}}\right)$ rather than the alternative $j$ or utility of alternative $i\left(\mathrm{U}_{\mathrm{in}}\right)$ is greater than utility of alternative $\mathrm{j}\left(\mathrm{U}_{\mathrm{in}}\right)$ is represented in Equation 2 and can be transformed into Equation 3 as shown below:

$$
\begin{aligned}
\operatorname{Pr}\left(\mathrm{i} \mid \mathrm{C}_{\mathrm{n}}\right) & =\operatorname{Pr}\left[\mathrm{U}_{\mathrm{in}}>\mathrm{U}_{\mathrm{jn}}\right] \\
& =\operatorname{Pr}\left[\mathrm{V}_{\mathrm{in}}+\varepsilon_{\mathrm{in}}>\mathrm{V}_{\mathrm{jn}}+\varepsilon_{\mathrm{jn}}\right] \\
\operatorname{Pr}\left(\mathrm{i} \mid \mathrm{C}_{\mathrm{n}}\right) & =\operatorname{Pr}\left[\mathrm{V}_{\mathrm{in}}-\mathrm{V}_{\mathrm{jn}}>\varepsilon_{\mathrm{jn}}-\varepsilon_{\mathrm{in}}\right]
\end{aligned}
$$

The probabilities that individual $n$ will choose alternative $i \operatorname{Pr}\left(\mathrm{i} \mid \mathrm{C}_{\mathrm{n}}\right)$ equal to the probability that $\left(\mathrm{V}_{\text {in }}\right.$ - $\left.\mathrm{V}_{\mathrm{jn}}\right)$ is greater than $\left(\varepsilon_{\mathrm{jn}}-\varepsilon_{\mathrm{in}}\right)$ even though the random components are unobservable [4]. The Conditional Logistic (CL) model is commonly used to determine the utility function from the choicebased data [4,8] According to the CL model, the functional form of the systematic utility function is given by the following linear utility function [8].

$$
\mathrm{V}_{\text {in }}=A S C+\sum_{k}^{k} \beta_{k} X_{k}
$$

where $\mathrm{V}_{\text {in }}$ is the systematic utility of alternative $i$ for individual $n$, ASC is the alternative specific 
constant, $\sum \beta_{\mathrm{k}} X_{\mathrm{k}}$ is the summation of all the coefficients of attribute $\mathrm{X}_{\mathrm{k}}$ and $i=1, \ldots, I$ represents the number of alternatives. It can be assumed that the coefficient values provide the relative importance of attributes or elements in consumer choice [9]. Finally, the utility function in the basic Condition Logistic model for dog food attributes is given by Equation 5, as followings:

$\beta_{\mathrm{CAN}}(\mathrm{CAN})+\beta_{\mathrm{POU}}(\mathrm{POU})+\beta_{\mathrm{DRY}}$

Utility $(\mathrm{DRY})+\beta_{\mathrm{PRI}}(\mathrm{PRI})+\beta_{\mathrm{UNB}}$ value $=$

$$
\begin{aligned}
& (\mathrm{UNB})+\beta_{\mathrm{COM}}(\mathrm{COM})+\beta_{\mathrm{PRE}} \\
& (\mathrm{PRE})+\beta_{\mathrm{FUL}}(\mathrm{FUL})+\beta_{\mathrm{SIL}}(\mathrm{SIL}) \\
& +\beta_{\mathrm{DOG}}(\mathrm{DOG})+\mathrm{ASC}
\end{aligned}
$$

\section{THE EMPIRICAL ANALYSIS}

\subsection{Screening and selecting attributes}

In the empirical application of $\mathrm{CBC}$, the first step is to identify and screen attributes and elements. Since there are different dog food products available between Thailand and Singapore, we selected the attributes and elements for each group of consumers separately. For Thai consumers, a first set of attributes and elements was obtained from the literature. After discussion with target consumers $(n=30)$, the final set of attributes and elements was established [5,12]. For Singaporean consumers the attributes were obtained from focus group discussions $(n=25)$. Predefined set of attributes and elements for both countries were identified (Figure 1 and 2.)
In CL model, the product attributes can be nominal, ordinal or even quantitative scales of measurement [10]. The ASC variable in the CL model is an alternative specific constant for dog food model. The coefficient values of elements are denoted as $\beta \mathrm{i}_{\mathrm{s}}$. For the CL model with a categorical dependent variable, the goodness of fit can be accessed through rho-square or pseudo $\mathrm{R}^{2}$ following Macfadden's $\mathrm{R}^{2}$ estimation method [11].

In this study, the empirical analysis used consumer-level questionnaires to elicit the information, regarding to four attributes (packaging format, price, brand quality and nutrition) with three levels of each predefined element (for Thai consumers, packaging format: canned, pouch, dry; price: 85 Baht, 135 Baht, 165 Baht per kg; brand quality: unbranded, commercial, premium; nutrition: fulfilled, silky fur and skin condition, dog's preference for nutrition; for Singaporean consumers: packaging format: canned, pouch, dry for format; price : < $\mathrm{S} \$ 5, \mathrm{~S} \$ 5-\$ 7,>\mathrm{S} \$ 7$ per $\mathrm{kg}$; brand quality: supermarket, premium, holistic for brand quality; general, specific, dog's preference for nutrition).

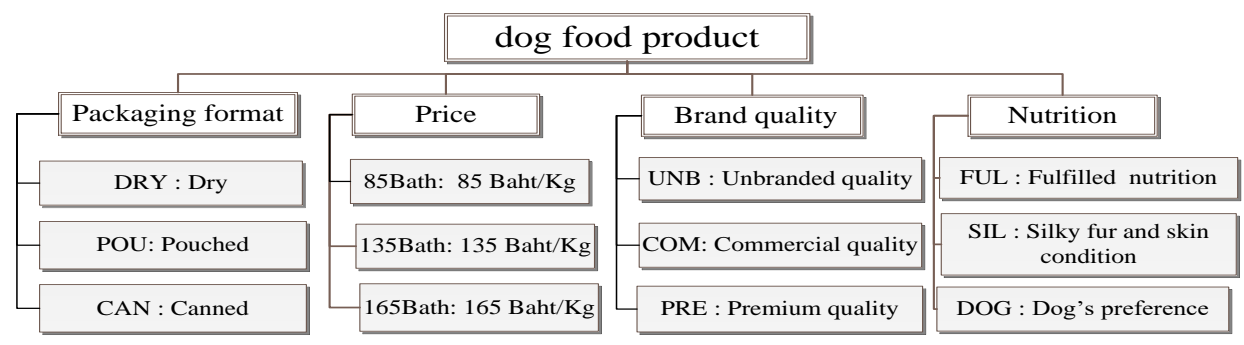

Figure 1. The attributes and elements for Thai consumers 


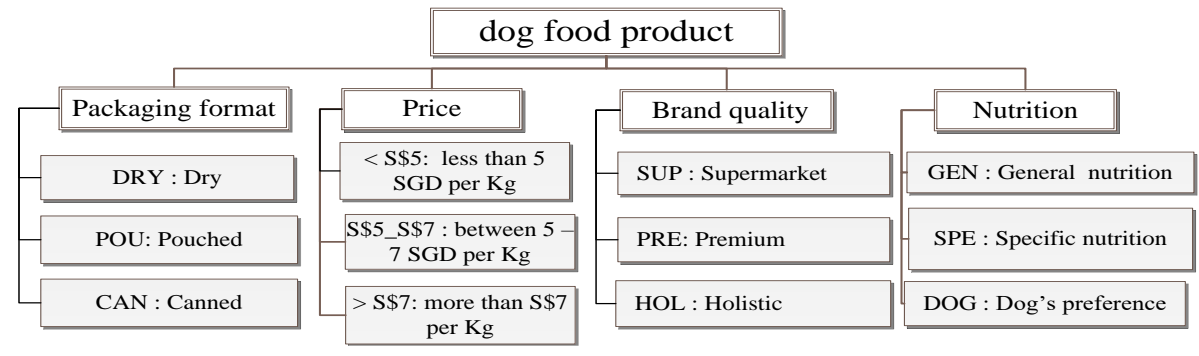

Figure 2. The attributes and elements for Singaporean consumers

\subsection{Creating the questionnaire}

The questionnaires were created by using the final set of attributes and elements as guided by the study of Aizaki and Nishimura [7]. The choice sets presented to respondents were created using an experimental design with respect to four attributes containing three elements. The number of choice set presented to each target group created by full factorial design was equal to $3^{4}=81$ choice sets. In order to avoid an overload effect for respondents, we used fractional factorial design to reduce the number of choice sets by the "optFederov function" of the Algdesign package [13] with $\mathrm{R}$ program [14]. At final, the total set of choice sets presented to each respondent was nine. The consumer had to choose the most preferred alternative in each choice set ("Alternative A", "Alternative B" and "no-choice").

\subsection{Data collection and data analysis}

Dog owners who live in Thailand (Bangkok area) and Singapore were chosen to fill the CBC questionnaire. There were 184 and 141 respondents in Thailand and Singapore respectively.

After all respondents had selected one of three alternatives in the nine choice sets, the CL model was used to estimate the utility values of dog food products from Thai and Singaporean consumers. Data analysis was performed by using the survival package [15] in R program version 2.13.0 to achieve the CL model. In order to be able to compare the results between Thai and Singaporean consumers, we considered the attributes and elements of dog food that explain the utility function, regardless of interaction effect between attributes.

\section{RESULTS AND DISCUSSION}

\subsection{Thai consumers}

Table 2 shows the results of CBC for Thai consumers $(n=184)$ derived from the CL model. According to the likelihood ratio test $(\mathrm{p}=0.000)$, we can reject the null hypothesis "all coefficients were equal to zero" at $99.99 \%$ confidential level. Moreover, the goodness of fit can be accessed through rho-square. For Thai consumers, the rhosquare was equal to 0.2721. As McFadden [16] noted, any rho-square greater than 0.2 indicates model sufficiency [11].

Dry dog food was the most preferred element, followed by "canned" and "pouch". For the "price" elements, the coefficient values were 0.10692, 0.07555, -0.18247 for 85 Baht per Kg, 135 Baht per $\mathrm{Kg}$ and 165 Baht per Kg which were close to zero. It can be assumed that price element did not have a major effect on the utility value $(p<0.05)$. For brand quality, the most preferred element was "Premium" element. In addition, for nutrition elements, the most preferred elements was "Silky fur and skin condition", followed by "fulfilled nutrition" and "dog's preference" subsequently.

Thus, the utility function for Thais consumer could be presented in the linear regression model given by:

\section{Trang 76}


Utility value Thais $=\quad-0.45049(\mathrm{CAN})-0.51199(\mathrm{POU})$

+0.96248 (DRY) + $0.10692(85 \mathrm{Bht})$

+0.07555 (135Bht $)-0.18247$

(165Bht) - 1.62644 (UNB) -

$0.50783(\mathrm{COM})+2.13427(\mathrm{PRE})+$

0.17649 (FUL) +0.89681 (SIL) -

$1.07330(\mathrm{DOG})+2.18019$

From the utility function, it is assumed that consumers will choose the product concept with higher utility value. Positive coefficients contributing to high utility value were associated with the element "premium", "dry", "silky fur and skin condition" and negative coefficients contributing to low utility value with the elements "unbranded", "dog's preference", "pouch", "commercial" and "canned". The results suggested that the product profile which contained elements of "premium", "dry" and "silky fur and skin condition" have high potential of success and preference by Thai consumers.

\subsection{Singaporean consumers}

The results from CL model for Singaporean consumers are shown in Table 3. The likelihood ratio test suggested that the null hypothesis was rejected at 99.99\% confidential level. The rho-square showed that the goodness of fit was equal to 0.1464 which was less than 0.2. However, the rho-square is still an acceptable range for the CL model [4]

Table 2. Results of the choice-based conjoint analysis for Thais consumers.

\begin{tabular}{|c|c|c|c|}
\hline Variables & Coefficient & Standard Error & $p$-value \\
\hline ASC & 2.18019 & 0.15586 & $0.00000 * * *$ \\
\hline Canned & -0.45049 & 0.15436 & 0.00352 \\
\hline Pouch & -0.51199 & 0.10880 & $0.00000 * * *$ \\
\hline Dry $^{a}$ & 0.96248 & 0.00000 & NA \\
\hline 85 Baht per $\mathrm{Kg}$ & 0.10692 & 0.08282 & 0.19673 \\
\hline 135 Baht per $\mathrm{Kg}$ & 0.07555 & 0.10951 & 0.49029 \\
\hline 165 Baht per $\mathrm{Kg}$ & -0.18247 & 0.00000 & NA \\
\hline Unbranded & -1.62644 & 0.11722 & $0.00000 * *$ \\
\hline Commercial & -0.50783 & 0.13051 & $0.00000 * *$ \\
\hline Premium $^{a}$ & 2.13427 & 0.00000 & NA \\
\hline Fulfilled & 0.17649 & 0.15717 & 0.26148 \\
\hline Silky fur and skin condition & 0.89681 & 0.09242 & $0.00000 * *$ \\
\hline Dog's preference $^{a}$ & -1.07330 & 0.00000 & NA \\
\hline \multicolumn{4}{|l|}{ Summary statistics } \\
\hline \multicolumn{4}{|c|}{ No. of observations $\quad 184$} \\
\hline \multicolumn{4}{|c|}{ Likelihood ratio test $=957.6$ on $9 \mathrm{df}, p$-value $=0.000$} \\
\hline rho-squared $(\mathrm{RHO} 2)^{\mathrm{c}}$ & \multicolumn{3}{|c|}{$\begin{array}{l}\text { on } 9 \text { ai, } p \text {-value }=0.000 \\
0.2721\end{array}$} \\
\hline Adjust rho-square (AdjRHO2) & \multicolumn{3}{|l|}{$\begin{array}{l}21 \\
0.2647\end{array}$} \\
\hline
\end{tabular}

a Significant codes: 0 '***' 0.001 '**' 0.01 '*' 0.5 '? 0.1 ' 1

${ }^{\mathrm{b}}$ Based element of attributes : coefficient of the base elements $(\beta 0)$ were calculated as $(\beta 1+\beta 2) \mathrm{x}(-1)$ following the effect coding procedure.

c The rho-squared (RHO2) also called Mcfadden's $\mathrm{R}^{2}$ or pseudo R squares

$\mathrm{NA}$ variances and p-values can be obtained by re-estimating the model by changing the based element.

Table 3. Results of the choice-based conjoint analysis for Singaporean consumers. 


\begin{tabular}{|c|c|c|c|c|}
\hline Variables & Coefficient & Standard Error & $p$-Value & \\
\hline ASC & 1.68561 & 0.18050 & 0.00000 & $* * * a$ \\
\hline Canned & -1.11531 & 0.13889 & 0.00000 & $* * *$ \\
\hline Pouch (wet food) & -2.04144 & 0.13421 & 0.00000 & $* * *$ \\
\hline Dry $^{b}$ & 3.15675 & 0.00000 & NA & \\
\hline$<\mathrm{S} \$ 5$ per kg & -0.28302 & 0.14250 & 0.04700 & $*$ \\
\hline $\mathrm{S} \$ 5-7$ per $\mathrm{kg}$ & 0.27676 & 0.14121 & 0.05000 & \\
\hline$>\mathrm{S} \$ 7$ per $\mathrm{kg}^{\mathrm{b}}$ & 0.00626 & 0.00000 & NA & \\
\hline Supermarket & -1.40132 & 0.12348 & 0.00000 & $* * *$ \\
\hline Premium & -0.15897 & 0.12558 & 0.20600 & \\
\hline Holistic $^{\mathrm{b}}$ & 1.56029 & 0.00000 & NA & \\
\hline General nutrition & 0.09709 & 0.15313 & 0.52600 & \\
\hline Specific nutrition & 0.24698 & 0.19134 & 0.19700 & \\
\hline Dog's preference ${ }^{b}$ & -0.34407 & 0.00000 & NA & \\
\hline \multicolumn{5}{|l|}{ Summary statistics } \\
\hline No. of observations & 141 & & & \\
\hline Rho-squared $^{\mathrm{c}}$ & 0.1464 & & & \\
\hline Adjust rho-square (RHO) & 0.1371 & & & \\
\hline \multicolumn{5}{|c|}{ Likelihood ratio test $=408.3$ on $9 \mathrm{df}, p$-value $=0.000$} \\
\hline
\end{tabular}

a Significant codes: 0 '***' 0.001 '**' 0.01 '*’ 0.5 '.' 0.1 ' 1

${ }^{\mathrm{b}}$ Based element of attributes : coefficient of the base elements $(\beta 0)$ were calculated as : $(\beta 1+\beta 2) \times(-1)$ following the effect coding procedure.

c The rho-squared (RHO2) also called Mcfadden's $\mathrm{R}^{2}$ or pseudo R squares.

$\mathrm{NA}$ variances and p-values can be obtained by re-estimating the model by changing the based element.

Considering elements within each attribute, "dry" was the most appreciated, followed by "canned" and "pouch". For the price attribute, the highest price, "> S\$7", did not contribute to the utility value. The most preferred element was "S\$5-S\$7" and the least preferred element was " $<\mathrm{S} \$ 5$ ". For brand quality, "holistic brand" was the most preferred, compared to "premium" and "supermarket". For nutrition, "general" was the most preferred element followed by "specific" and "dog's preference". The utility function of dog food product for Singaporean is shown below:

$\begin{aligned} \text { Utility value Thais }= & -1.11531(\mathrm{CAN})-2.04144(\mathrm{POU})+ \\ & 3.15675(\mathrm{DRY})-0.28302(<\mathrm{S} \$ 5)+ \\ & 0.27676\left(\mathrm{~S} \$ 5 \_\mathrm{S} \$ 7\right)-0.00626(>\mathrm{S} \$ 7) \\ & -1.40132(\mathrm{SUP})-0.15897(\mathrm{PRE}) \\ & +1.56029(\mathrm{HOL})+0.09709(\mathrm{GEN}) \\ & +0.24689(\mathrm{SPE})-0.34407(\mathrm{DOG})+ \\ & 1.68561\end{aligned}$

From the utility function, positive coefficients contributing to high utility value were associated with the element "dry", "holistic", "S\$5-S\$7", "specific nutrition" and negative coefficients contributing to low utility value with the elements "pouch", "supermarket", "canned", "dog's preference", " $<\mathrm{S} \$ 5$ ", "premium". These results suggested that the product with the higher potential for Singaporean consumers was the product profile which contained the elements "dry", "holistic", "S\$5-S\$7" and "specific" elements.

\subsection{Comparison between Thai and Singaporean consumers.}

To compare the consumer preference between Thais and Singaporean, we considered the coefficient values of each element presented in Figure 3. Some similarities can be observed from both groups. Regarding packaging format, both Thai and Singaporean consumers showed the same appreciation of "dry" element rather than "canned" and "pouch". This could be due to the wide 
availability and convenience of dry foods from consumer who follow an urban life style $[17,18]$.

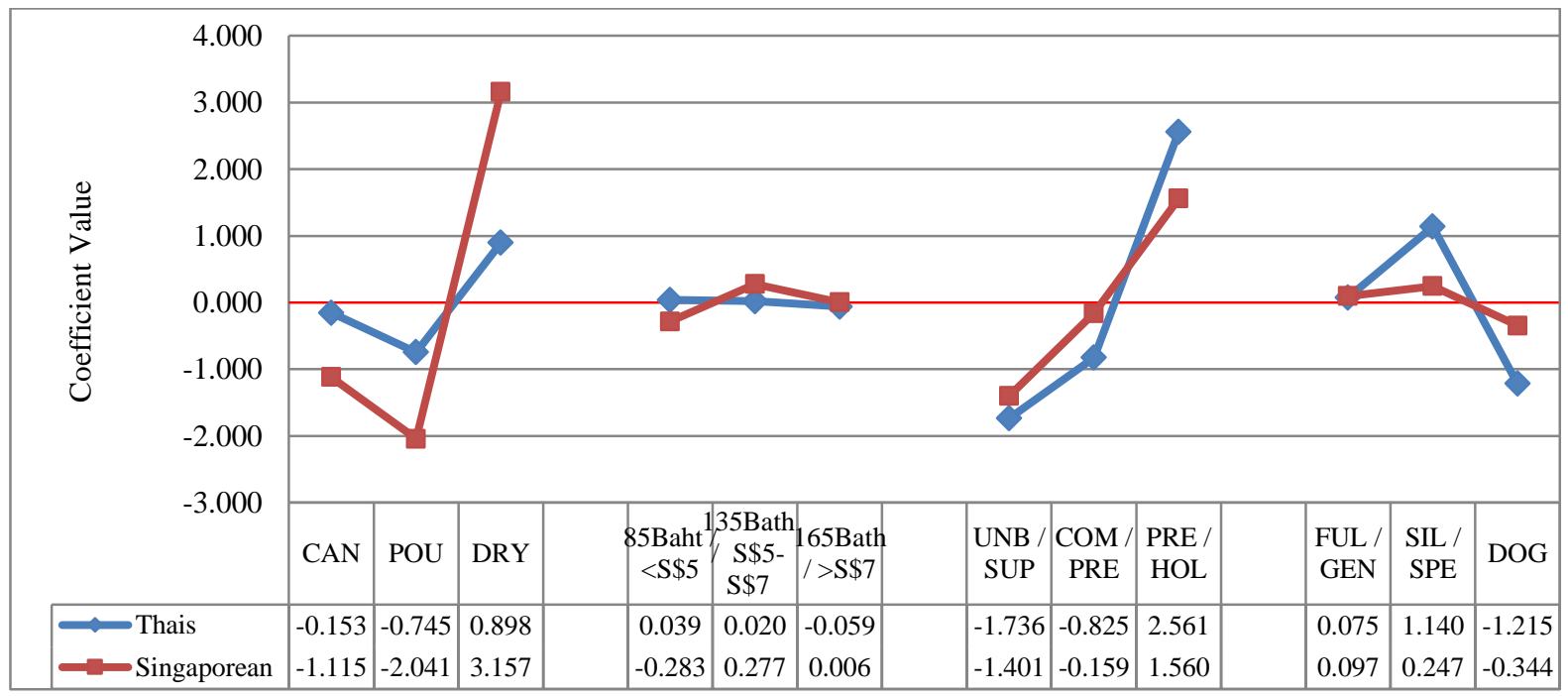

Figure 3. Comparison of consumer preference between Thai and Singaporeans

* NB: All codes are denoted as elements as previously defined in Figure 1 and 2 . $(\mathrm{CAN}=$ canned, $\mathrm{POU}=$ pouch, $\mathrm{DRY}=$ dry; 85Baht $=85$ Baht per Kg, 125 Baht $=125$ Baht per Kg, 165Baht = 165 Baht per Kg; <S $\$ 5=$ less than 5 SGD, S $\$ 5-$ $\mathrm{S} \$ 7$ = between 5 to $7 \mathrm{SGD},>\mathrm{S} \$ 7=$ more than $7 \mathrm{SGD} ; \mathrm{UBN}=$ unbranded brand quality, $\mathrm{COM}=$ commercial brand quality, PRE = premium quality, SUP = supermarket brand quality, HOL = holistic brand quality; FUL = fulfilled nutrition, SIL = silky fur and skin condition, $\mathrm{DOG}=\mathrm{dog}$ 's preference, $\mathrm{GEN}=$ general nutrition, $\mathrm{SPE}=$ specific nutrition)

For the brand quality attribute, Thai and Singaporean consumers showed higher preference scores when dog food product contained higher brand quality element. The highest brand quality element for Thai consumers was "premium", while for Singaporean consumers it was "holistic". Agriculture and Agri-food Canada (2010) [1] had reported that dog owners considered that the food they feed their dogs should be as good as what they consume themselves.

For the nutritional attribute, it was found that both countries preferred dog food to have specific functional properties. Thai and Singapore consumers gave higher preference scores to dog foods that contain the "silky fur and skin" element and "specific" element respectively, compared to "fulfilled", "general" and "dog's preference" which received lower preference scores. It should be noted that the "price" attribute did not contribute significantly to consumer preferences in both countries.

In addition, it was found that the "dry" and "premium" or "holistic" elements were the main dominating attributes for Thai and Singaporean consumers. The results from $\mathrm{CBC}$ showed an overestimation in "premium" element for Thai and "holistic" element for Singaporean consumers. This may have resulted from respondent giving increasing weight to their preferences and ignoring other elements.

\section{CONCLUSION}

We focused on assessing the difference in perception of dog food product between Thais and 
Singaporean consumers by using CBC method. The CBC method allows product developers to identify relevant attributes and elements that influenced consumer's preference on dog food. It was found that dry dog food and high brand quality were the main dominating attributes for both countries. Functional properties that provide health and wellness impacted also the preference. Finally, the price attribute did not contribute significantly to respondent preferences.

This study demonstrates that the CBC method is an interesting and practical method to be applied in food science for measuring the preference of dog food products which are not directly consumed by human. The CBC seems to be realistic and friendly to consumers by asking to choose the most preferred product among the alternative products within choice sets. This simulates what the consumer does at the marketplace. However, the $\mathrm{CBC}$ does not allow determining the preference score at individual level. Future studies should focus on the effects of individual characteristics such as gender, number of dogs and purpose for having a dog, in order to better understand different perceptions of consumers.

\section{So sánh thị hiếu đối với thức ăn dành cho chó giữa người tiêu dùng Thái Lan và Singapore sử dụng phương pháp phân tích đánh đổi dựa trên sự lựa chọn (choice-based conjoint analysis)}

- Phaosathienpan Sarun ${ }^{a *}$

- Leong Jasmine ${ }^{b}$

- Tengpongsathon Kallayanee ${ }^{a}$

${ }^{a}$ Food Science Division, Faculty of Agro- Industry, King Mongkut's Institute of Technology Ladkrabang, Bangkok, Thailand 10520.

${ }^{b}$ School of Chemical and Life Sciences, Singapore Polytechnic, 500, Dover Road Singapore 139651

\section{TÓM TÁ̀T}

Nghiên cứu nhằm tìm hiểu sự khác biệt về mặt cảm nhận khi lựa chọn thức ăn dành cho chó giữa người tiêu dùng Thái Lan và người tiêu dùng Singapore sử dụng phương pháp phân tích đánh đổi dựa trên sự lựa chọn (Choice-
Based Conjoint analysis, viết tắt là $C B C$ ). Nghiên cứu sử dụng bảng câu hỏi về mức độ tiêu dùng (với cỡ mẫu $n=184$ người tiêu dùng Thái Lan và $n=141$ người tiêu dùng Singapore) nhằm khai thác thông tin liên quan đến bốn 
thuộc tính (attributes) về dạng bao bì, giá cả, chất lượng thương hiệu, và dinh dưỡng. Mỗi thuộc tính có 3 yếu tố (elements) được định nghĩa trước.

Đối với người tiêu dùng Thái Lan, 3 yếu tố tương ứng với từng thuộc tính như sau, dạng bao bì: đóng lon, đóng túi (bịch), hạt khô (không bao bi); giá cả: 85, 135, $165 \mathrm{Baht}^{1} / \mathrm{kg}$; chất lượng thương hiệu: không có thương hiệu, sản phẩm thương mại, sản phẩm cao cấp; dinh duỡng: toàn diện (fulfilled), dương da và lông, phù hợp sở thích. Đối với người tiêu dùng Singapore, 3 yếu tố tương ứng với từng thuộc tính nhu sau, dạng bao bi: đóng lon, đóng túi (bịch), hạt khô (không bao bì); giá cả: thấp hơn 5 , từ 5 đến 7 , lớn hơn $7 S G D / k g$, chất lượng thương hiệu: siêu thị, cao cấp, holistic; dinh dưỡng: toàn diện, nhu cầu đặc biệt, phù hợp sở thich.

\section{REFERENCES}

[1]. A. a. A.-F. Canada. (2010). Global pet food trends.

Available:

http://www.gov.mb.ca/agriculture/statistics/foo d/global_pet_food_en.pdf

[2]. E. International. (2012, 2 Apr.). Pet humanization continues to drive the global pet care market. Available: http://blog.euromonitor.com/2012/08/pethumanization-continues-to-drive-the-globalpet-care-market.html

[3]. K. Koppel, "Sensory analysis of pet foods," Journal of the Science of Food and Agriculture, 2014.

[4]. Z. Kallas, F. Lambarraa, and J. M. Gil, "A stated preference analysis comparing the analytical hierarchy process versus choice experiments," Food quality and preference, vol. 22, pp. 181-192, 2011.

[5]. S. Phaosathienpan and K. Tengpongsathon, "Application of Choice-Based Conjoint
Kết quả phân tích hồi quy logistic có điều kiện (conditional logistic regression) chỉ ra rằng: sản phẩm dạng hạt khô, chất lượng cao cấp, có tác dụng dưỡng da và lông là các yếu tố quan trọng để lựa chọn đối với người tiêu dùng Thái Lan. Trong khi đó, sản phẩm dạng hạt khô, chất lượng thương hiệu holistic, đáp ứng được nhu cầu dinh dưỡng đặc biệt là các yếu tố quan trọng để lựa chọn đối với người tiêu dùng Singapore. Thuộc tính giá cả không có ảnh hưởng đáng kể đến thị hiếu của người tiêu dùng ở cả hai nước. Bên cạnh đó, phân tích CBC cũng chỉ ra một ước lượng quá mức (overestimation) trong giá trị của các yếu tố đối với các sản phẩm thức ăn dành cho chó. Việc so sánh các kết quả $C B C$ giữa hai nước đã giúp xác định được các thuộc tính tiềm năng đối với loại sản phẩm này.

Analysis for consumer preference on dog's pet food product in Thailand," in SPISE 2012 Integrating sensory evaluation to product development, An Asian perspective, University of technology, Ho Chi Minh City, 2012.

[6]. R. Haaijer and M. Wedel, "Conjoint choice experiments: General characteristics and alternative model specifications," in Conjoint Measurement, ed: Springer, 2003, pp. 371-412.

[7]. H. Aizaki and K. Nishimura, "Design and analysis of choice experiments using R: a brief introduction," Agricultural Information Research, vol. 17, pp. 86-94, 2008.

[8]. M. Ryan and K. Gerard, "Using discrete choice experiments to value health care programmes: current practice and future research reflections," Applied health economics and health policy, vol. 2, pp. 55-64, 2003.

[9]. S. Colombo, A. Angus, J. Morris, D. J. Parsons, M. Brawn, K. Stacey, and N. Hanley, 
"A comparison of citizen and "expert" preferences using an attribute-based approach to choice," Ecological Economics, vol. 68, pp. 2834-2841, 2009.

[10]. M. Meißner and R. Decker, "An empirical comparison of $\mathrm{CBC}$ and AHP for measuring consumer preferences," in International Symposium of Analytical Hierarchy Process, 2009.

[11]. N. Novotorova, "A Conjoint Analysis of Consumer Preferences for Product Attributes: The Case of Illinois Apples," University of Illinois at Urbana-Champaign2007.

[12]. S. Phaosathienpan, "Comparision of ChoiceBased Conjoint Analysis and Analytical Hierarchy Process in consumer preference of dog food," MsD thesis, Faculty of AgroIndustry, King Mongkut's Institute of Technology Ladkrabang, Bangkok, Thailand: , 2014.
[13]. B. Wheeler and M. B. Wheeler, "The AlgDesign Package," ed, 2008.

[14]. R. C. Team, "R: A Language and Environment for Statistical Computing. R Foundation for Statistical Computing, Vienna, Austria, 2012," ISBN 3-900051-07-02012.

[15]. T. Therneau, "A package for survival analysis in S. R package version 2.37-4," ed, 2013.

[16]. D. McFadden, "Conditional logit analysis of qualitative choice behavior," 1972.

[17]. K. Naksuwan, "Marketing factors attesting dog ready food buying decision in Bangkok metropolis," Department of management, Rajamangala University of Technology Thanyaburi, Patumtani Thailand2006.

[18]. E. International. (2013, 1Apr.). Country report: dog food in Thailand Available: http://www.euromonitor.com /dog-food-inthailand/report 